\title{
Aplikasi Analisis Spasial Untuk Penentuan Zona Imbuhan Dan Zona Lepasan Airtanah, Cekungan Air Tanah (CAT) Karangkobar, Provinsi Jawa Tengah
}

\author{
Agus Harjanto ${ }^{1}$, Thomas Triadi Putranto ${ }^{2,3}$, dan Truman Simaremare ${ }^{2}$
}

1Jurusan Teknik Geologi Fakultas Teknologi Mineral UPN "Veteran" Yogyakarta; e-mail: aharjanto69@yahoo.com

${ }^{2}$ Departemen Teknik Geologi Fakultas Teknik Universitas Diponegoro

${ }_{3}^{3}$ Magister Ilmu Lingkungan, Sekolah Pascasarjana Universits Diponegoro

\begin{abstract}
ABSTRAK
Cekungan Air Tanah (CAT) Karangkobar terletak di wilayah administrasi Kabupaten Banjarnegara dan Kabupaten Wonosobo. CAT Karangkobar memiliki luas sekitar 299,6 km2. Daerah ini terletak di daerah dengan kondisi geologi yang banyak dipengaruhi oleh aktivitas vulkanisme. Secara regional sistem akuifer pada daerah ini merupakan sistem akuifer dengan aliran air tanah melalui ruang antar butir dan rekahan. Tujuan dari penelitian ini adalah untuk mendeliniasi daerah imbuhan dan daerah lepasan air tanah di CAT Karangkobar. Pengambilan data lapangan dilakukan dengan mengamati kondisi geologi dan mengukur tinggi muka air tanah CAT Karangkobar. Penentuan zona imbuhan dan lepasan dilakukan dengan metode geospasial menggunakan perangkat lunak Surfer dan ArcGis. Metode ini dilakukan dengan pembobotan. Parameter yang digunakan dalam pembobotan ini terdiri dari 5 parameter, yaitu: kelulusan batuan, curah hujan, jenis tanah penutup, kemiringan lereng dan kedalaman muka air tanah tidak tertekan. Nilai maksimal yang didapat dari pembobotan ini adalah 65 sedangkan nilai minimal adalah 39. Daerah imbuhan berada pada nilai bobot 53-65, daerah ini berada dibagian utara CAT Karangkobar. Daerah lepasan berada pada nilai bobot 39-52, daerah ini berada pada bagian selatan CAT Karangkobar..
\end{abstract}

Kata kunci: airtanah, cekungan airtanah Karangkobar, metode geospasial, daerah imbuhan dan daerah lepasan airtanah.

\begin{abstract}
Karangkobar groundwater basin located in Banjarnegara District and Wonosobo District. Karangkobar groundwater basin area is about 299,6 km2. This area is located in a region with geological condition which is heavily affected by volcanism activity. Regionally, aquifer system in this region is aquifer system with groundwater flow through pore spaces and fractures. The purpose of this research is to deliniate recharge and discharge zone of groundwater in Karangkobar groundwater basin. Field data retrieval was done by observing geological condition and measuring groundwater level, in Karangkobar groundwater basin. Recharge and discharge zone determination is done by geospatial method using Surfer and ArcGis software. This method is done with scoring method. Parameters used in this scoring consists of 5 parameters: permeability of rock, rainfall, soil type, slope and depth of superficial groundwater level. Maximum value in this scoring is 65 and minimum value is 39. Recharge zone score is on 53-65, which is located in the north of Karangkobar groundwater basin with. Discharge zone score is on 39-52, which is located in the south of Karangkobar groundwater basin.
\end{abstract}

Keywords: groundwater, Karangkobar groundwater basin, geospatial method, recharge and discharge zone.

Sitasi: Harjanto, A., Putranto, T.T., dan Simaremare, T.(2018 Aplikasi Analisis Spasial Untuk Penentuan Zona Imbuhan Dan Zona Lepasan Airtanah, Cekungan Air Tanah (CAT) Karangkobar, Provinsi Jawa Tengah. Jurnal Ilmu Lingkungan, 16(2), 162-172, doi:10.14710/jil.17.2.162-172

\section{Pendahuluan}

Air adalah salah satu sumber daya alam yang dapat diperbaharui. Air tanah merupakan sumber daya alam yang vital dalam menyediakan pasokan air minum yang bersih baik di dearah pedesaan maupun perkotaan (Magesh dkk., 2012).Kebutuhan akan air bersih semakin lama semakin meningkat, hal ini akan mempengaruhi ekosistem air di daerah pasokan air tanah, dan di daerah lepasan air tanah, untuk itu perlu dilakukan perlindungan air tanah (Lewis, 2016). Laju pertumbuhan penduduk dan aktivitasnya akan selalu berbanding lurus dengan kebutuhan akan air tanah. Hal ini mendorong terjadinya eksploitasi terhadap sumber daya air tanah yang akan dapat 
Harjanto, A., Putranto, T.T., dan Simaremare, T.(2018 Aplikasi Analisis Spasial Untuk Penentuan Zona Imbuhan Dan Zona Lepasan Airtanah, Cekungan Air Tanah (CAT) Karangkobar, Provinsi Jawa Tengah. Jurnal IImu Lingkungan, 16(2), 162-172, doi:10.14710/jil.17.2.162-172

mengakibatkan perubahan dari fungsi lahan. Penggunaan dan pemanfaatan lahan yang kurang bijaksana dapat merusak dan menurunkan kuantitas dan kualitas air tanah.

Daerah imbuhan secara umum berada pada daerah perbukitan, daerah tinggian, pegunungan dan biasanya menjadi daerah aliran air sementara. Proses pengimbuhan melibatkan gerakan air masuk kedalam akuifer. Daerah lepasan melibatkan keluarnya air dari dalam akuifer. Daerah lepasan biasanya berada pada daerah rendahan dengan aliran air yang biasanya tetap seperti mata air, rawa, danau dan lautan (Rose, 2009). Penerapan analisis spasial banyak dilakukan dalam pemetaan potensi dan kondisi air tanah(Assatse et al. 2016; Elbeih. 2015; Senayake et al. 2015; Yeh et al. 2016).

\section{Geologi Regional}

Berdasarkan peta geologi regional yang disusun oleh Condon, dkk (1996), daerah air tanah (CAT) Karangkobarmasuk dalam Peta Geologi Lembar Banjarnegara-Pekalongan (Gambar 1). Formasi penyusun di daerah penelitian dari paling tua kemuda, yaitu:

- Formasi Rambatan (Tmr)

- Anggota Breksi Formasi Tapak (Tptb)

- Formasi Kalibiuk (Tpb)

- Batuan Intrusi (Tpb) Batuan tersusun atas diorit, meliputi variasi tak teruraikan (Tmi), kuarsanit (Tmk), diorit atau diorit porfir (Tmd), gabro atau porfir gabro (Tmpi)

- $\quad$ Anggota Lempung Formasi Ligung (QTlc)

- Anggota Breksi Formasi Ligung (QTlb)

- $\quad$ Batuan Gunungapi Jembangan (Qj)

- Endapan Danau dan Aluvium (Qla)

- $\quad$ Batuan Gunungapi Dieng (Qd)

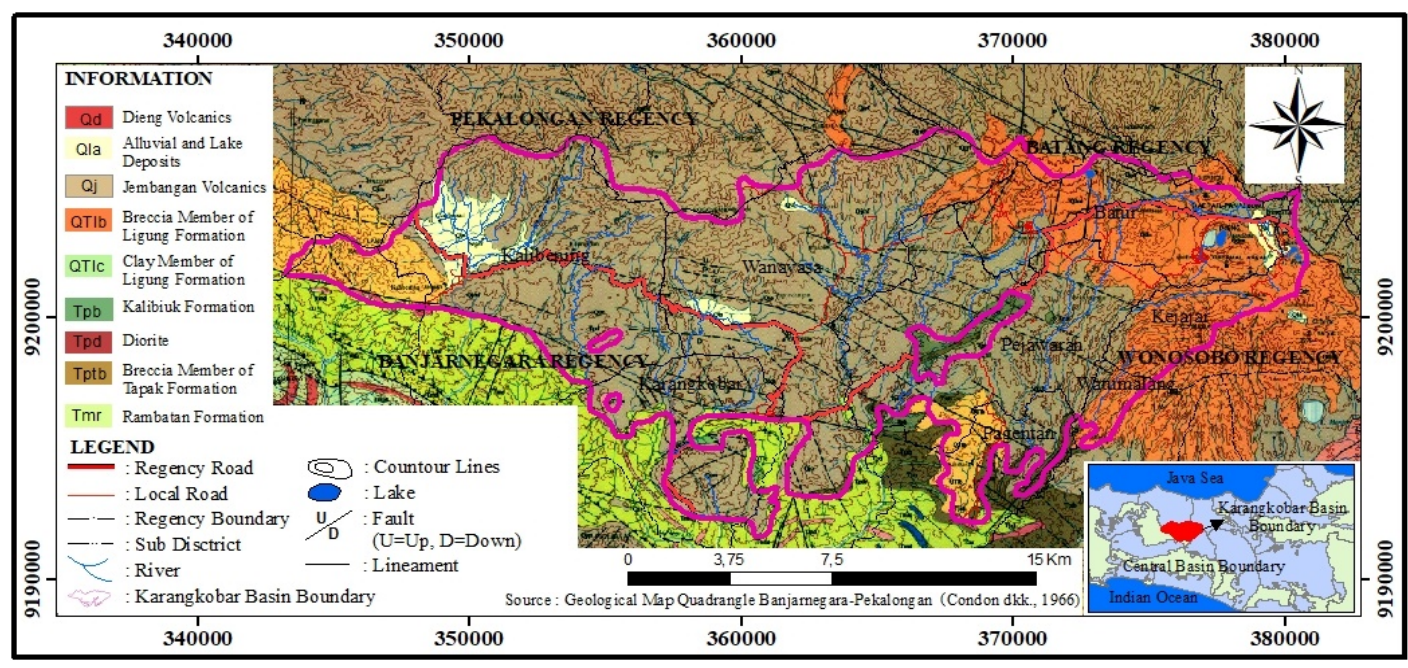

Gambar 1 Peta Geologi Regional Daerah Penelitian

\section{Penentuan Daerah Imbuhan dan Daerah Lepasan}

Menurut Danaryanto dkk. (2007), dalam penentuan zona imbuhan dan lepasan airtanah, terdapat 5 parameter klasifikasi yaitu: Kelulusan batuan, curah hujan, tanah penutup, kemiringan lereng, dan kedalaman muka airtanah tidak tertekan. Kelima parameter tersebut mempunyai tingkat pengaruh yang berbeda-beda terhadap meresapnya air kedalam tanah (Tabel 1). Parameter yang mempunyai bobot paling tinggi merupakan parameter yang paling menentukan kemampuan peresapan air untuk menambah airtanah secara alamiah pada suatu cekungan. Dari 5 parameter tersebut, masing-masing parameter memiliki kelas berdasarkan kemampuan peresapan air masuk kedalam tanah, kelas tersebut dapat dilihat dalam Tabel 2 sampai Tabel 6.

Tabel 1 Nilai Bobot Parameter Resapan Air (Danaryanto dkk., 2007).

\begin{tabular}{clcl}
\hline No. & Parameter & Nilai Bobot & \\
\hline 1. & Kelulusan batuan & 5 & Sangat tinggi \\
2. & Curah hujan & 4 & Tinggi \\
3. & Tanah penutup & 3 & Cukup \\
4. & Kemiringan lereng & 2 & Sedang \\
5. & Muka airtanah tidak tertekan & 1 & Rendah \\
\hline
\end{tabular}

Tabel 2 Nilai Peringkat Kelulusan Batuan (Danaryanto dkk., 2007).

\begin{tabular}{cccl}
\hline No. & Nilai Kelulusan Batuan (m/hari) & Nilai Peringkat \\
\hline 1. & $>10^{3}$ & 5 & Sangat tinggi \\
2. & $10^{1}-10^{3}$ & 4 & Tinggi \\
3. & $10^{-2}-10^{1}$ & 3 & Cukup \\
4. & $10^{-4}-10^{-2}$ & 2 & Sedang \\
5. & $<10^{-4}$ & 1 & Rendah \\
\hline
\end{tabular}


Tabel 3 Nilai Peringkat Curah Hujan (Danaryanto dkk., 2007).

\begin{tabular}{cccl}
\hline No. & Curah Hujan (mm/tahun) & \multicolumn{2}{c}{ Nilai Peringkat } \\
\hline 1. & $>4.000$ & 5 & Sangat tinggi \\
2. & $3.000-4.000$ & 4 & Tinggi \\
3. & $2.000-3.000$ & 3 & Cukup \\
4. & $1.000-2.000$ & 2 & Sedang \\
5. & $<1.000$ & 1 & Rendah \\
\hline
\end{tabular}

Tabel 4 Nilai Peringkat Tanah Penutup (Danaryanto dkk., 2007).

\begin{tabular}{clcl}
\hline No. & \multicolumn{1}{c}{ Tanah Penutup } & \multicolumn{2}{c}{ Nilai Peringkat } \\
\hline 1. & Kerikil & 5 & Sangat tinggi \\
2. & Pasir kerikilan & 4 & Tinggi \\
3. & Lempung pasiran/lanau pasiran & 3 & Cukup \\
4. & Lanau lempungan & 2 & Sedang \\
5. & Lempung lanauan & 1 & Rendah \\
\hline
\end{tabular}

Tabel 5 Nilai Peringkat Kemiringan Lereng (Danaryanto dkk., 2007).

\begin{tabular}{cccl}
\hline No. & Kemiringan Lereng (derajat) & \multicolumn{2}{c}{ Nilai Peringkat } \\
\hline 1. & $>40^{\circ}$ & 5 & Sangat tinggi \\
2. & $20-40^{\circ}$ & 4 & Tinggi \\
3. & $10-20^{\circ}$ & 3 & Cukup \\
4. & $5-10^{\circ}$ & 2 & Sedang \\
5. & $<5^{\circ}$ & 1 & Rendah \\
\hline
\end{tabular}

Tabel 6 Nilai Peringkat Kedalaman Muka Airtanah Tidak Tertekan (Danaryanto dkk., 2007).

\begin{tabular}{cccl}
\hline No. & $\begin{array}{c}\text { Kedalaman Muka Airtanah } \\
\text { Tidak Tertekan (m) }\end{array}$ & \multicolumn{2}{c}{ Nilai Peringkat } \\
\hline 1. & $>30 \mathrm{~m}$ & 5 & Sangat tinggi \\
2. & $20-30 \mathrm{~m}$ & 4 & Tinggi \\
3. & $10-20 \mathrm{~m}$ & 3 & Cukup \\
4. & $5-10 \mathrm{~m}$ & 2 & Sedang \\
5. & $<5 \mathrm{~m}$ & 1 & Rendah \\
\hline
\end{tabular}

\section{Metodologi}

Metode observasi dilakukan untuk mengamati seperti kondisi geologi permukaan, kondisi tanah penutup, bentuk topografi dan pengukuran muka air tanah tidak tertekan pada sumur bor/gali. Terdapat 33 data muka air tanah tidak tertekan yang diambil secara acak di daerah penelitian.

Tujuannya adalah untuk mengetahui tipe batas hidrogeologinya. Dari batas tersebut dapat diketahui kondisi hidraulik tanah yang memisahkan CAT daerah penelitian dengan CAT lainnya.

Analisis data spasial digunakan dengan melakukan pembobotan (Scoring). Dalam penentuannya, terdapat 5 parameter yang digunakan berdasarkan klasifikasi yang dibuat oleh Danaryanto dkk, (2007). Parameter tersebut dari pengaruh paling besar adalah parameter kelulusan batuan, curah hujan, tanah penutup, kemiringan lereng, dan kedalaman muka air tanah tidak tertekan

\section{Hasil dan Pembahasan}

\subsection{Penentuan Zona Imbuhan dan Lepasan Airtanah dengan Menggunakan Metode Spasial}

Dalam penentuan zona imbuhan dan lepasan air tanah di CAT Karangkobar, metode yang digunakan adalah metode geospasial. Metode ini adalah salah satu cara untuk mengolah data Sistem Informasi Geografi. Data ini sangat bergantung pada obyek letak yang bersangkutan. Metode geospasial ini dilakukan dengan menggabungkan (overlay) beberapa peta untuk menghasilkan peta atau informasi yang baru. Caranya adalah masing-masing parameter diberikan nilai peringkat lalu dikalikan dengan nilai bobotnya. Setelah setiap nilai bobot tiap parameter didapat, lalu dijumlahkan secara keseluruhan untuk mendapatkan nilai bobot total, lalu diberi kelas untuk menentukan daerah imbuhan dan daerah lepasan.

\subsection{Parameter Kelulusan Batuan}

Parameter kelulusan batuan memiliki nilai bobot tertinggi yaitu 5. Nilai kelulusan batuan dipengaruhi oleh variasi faktor fisika seperti porositas, ukuran dan distribusi butir, bentuk butir dan susunan butir.

Berdasarkan hasil pengamatan tersebut, maka daerah penelitian dapat dibagi menjadi 3 daerah yaitu daerah dengan dominasi breksi yang memiliki fragmen berukuran kerikil, daerah dengan dominasi batu pasir tuffan, dan daerah dengan tanah didominasi pasir seperti yang terlihat pada Gambar 2 6.

Menurut Morris dan Johnson (1975), dalam Todd dan Mays (2005), daerah dengan litologi breksi 
vulkanik memiliki nilai konduktivitas hidraulika batuan sebesar $270 \mathrm{~m} /$ hari. Breksi vulkanik merupakan jenis batuan yang tidak terkonsolidasi dengan baik. Breksi memiliki porositas yang tidak baik, ukuran butir yang relatif tidak seragam dan bentuk butir angular sehingga memiliki nilai konduktivitas yang tinggi. Daerah dengan nilai konduktivitas hidraulika batuan $270 \mathrm{~m} /$ hari berada di peringkat 4, sehingga nilai peringkat dikalikan dengan nilai bobot memiliki nilai skor sebesar 20.Batupasir tuffan memiliki nilai konduktivitas hidraulika batuan sebesar 3,1 $\mathrm{m} /$ hari. Batupasir tuffan ini diklasifikasikan sebagai batupasir ukuran sedang karena memiliki pasir dengan ukuran sedang dan bercampur dengan fragmen tuff. Batupasir memiliki porositas yang baik, ukuran butir yang seragam dan membundar dengan baik. Daerah dengan nilai konduktivitas hidraulika batuan 3,1 m/hari berada diperingkat 3 , sehingga nilai peringkat dikalikan dengan nilai bobot memiliki nilai skor sebesar 15 . Tanah yang didominasi pasir memiliki nilai konduktivitas hidraulika batuan sebesar 0,49 m/hari. Tanah didominasi pasir juga merupakan tanah yang tidak terkonsolidasi karena berasal dari material lepas dan telah banyak mengalami perubahan fisik. Daerah dengan nilai konduktivitas hidraulika batuan $0,49 \mathrm{~m} /$ hari berada diperingkat 3 , sehingga nilai peringkat dikalikan dengan nilai bobot memiliki nilai skor sebesar 15.

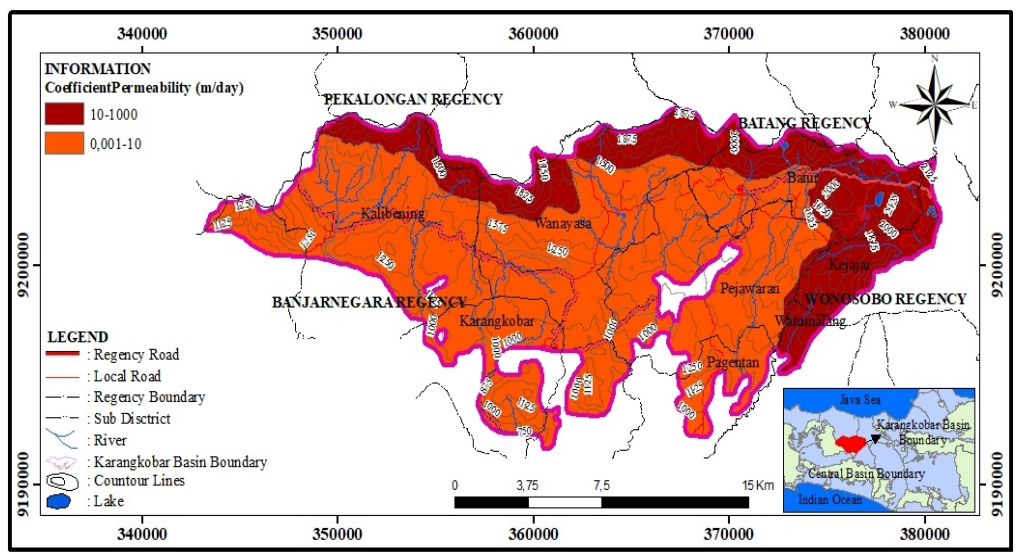

Gambar 2 Peta Kelulusan Batuan

Tabel 7 Perhitungan Skor Parameter Kelulusan Batuan

\begin{tabular}{|c|c|c|c|c|}
\hline Litologi & $\begin{array}{l}\text { Nilai Kelulusan } \\
\text { Batuan (m/hari) }\end{array}$ & $\begin{array}{c}\text { Nilai } \\
\text { Peringk } \\
\text { at }\end{array}$ & $\begin{array}{c}\text { Nil } \\
\text { ai } \\
\text { Bo } \\
\text { bot }\end{array}$ & $\begin{array}{l}\text { Sko } \\
\mathbf{r}\end{array}$ \\
\hline $\begin{array}{c}\text { Breksi Vulkanik } \\
\text { Batupasir } \\
\text { Sedang dan } \\
\text { Tanah, } \\
\text { Didominasi } \\
\text { Pasir }\end{array}$ & $\begin{array}{l}10^{1}-10^{3} \\
10^{-2}-10^{1}\end{array}$ & $\begin{array}{l}4 \\
3\end{array}$ & $\begin{array}{l}5 \\
5\end{array}$ & $\begin{array}{l}20 \\
15\end{array}$ \\
\hline
\end{tabular}

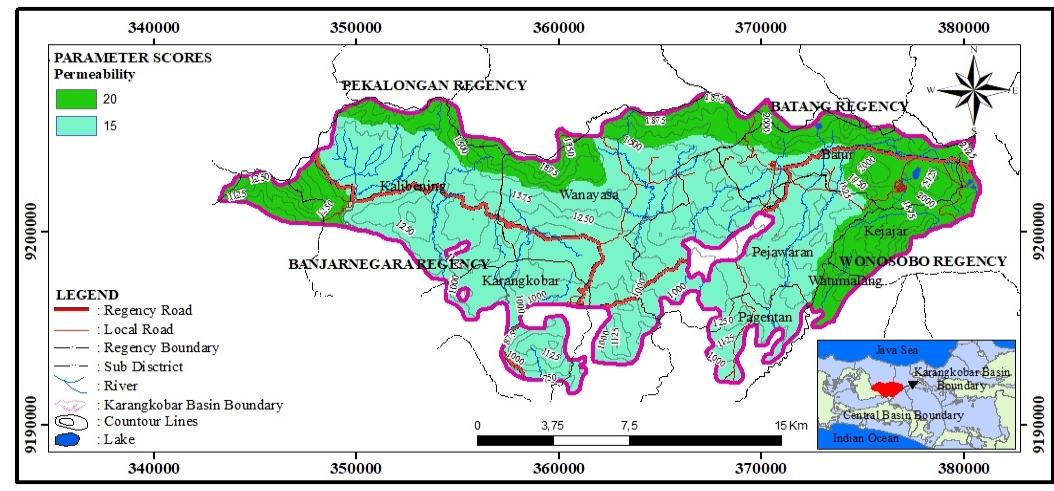

Gambar 3 Peta Skor Kelulusan Batuan

Daerah-daerah tersebut dapat diklasifikasikan menjadi 2 daerah menurut Danaryanto dkk. (2007). Perhitungan data skor dapat dilihat pada Tabel 7 dan selanjutnya disajikan dalam peta skor kelulusan batuan (Gambar 3). 


\subsection{Parameter Curah Hujan}

Parameter curah hujan memiliki nilai bobot 4 . Berdasarkan data besarnya curah hujan yang diambil dai BPS Kabupaten Banjarnegara dan BPS Kabupaten Wonosobo 2017, rata-rata curah hujan pertahun di CAT Karangkobar adalah sebesar 366,5 mm/tahun dan rata-rata curah hujan secara keseluruhan adalah $4.350,1 \mathrm{~mm} /$ tahun.
Dari data curah hujantersebut,daerah penelitian dibagi menjadi 3 kelas curah hujan (Danaryanto dkk., 2007) (Gambar 4), hal ini karena jumlah curah hujan yang berada di CAT Karangkobar berada dalam rentang $2.000->4.000 \mathrm{~mm} /$ tahun.

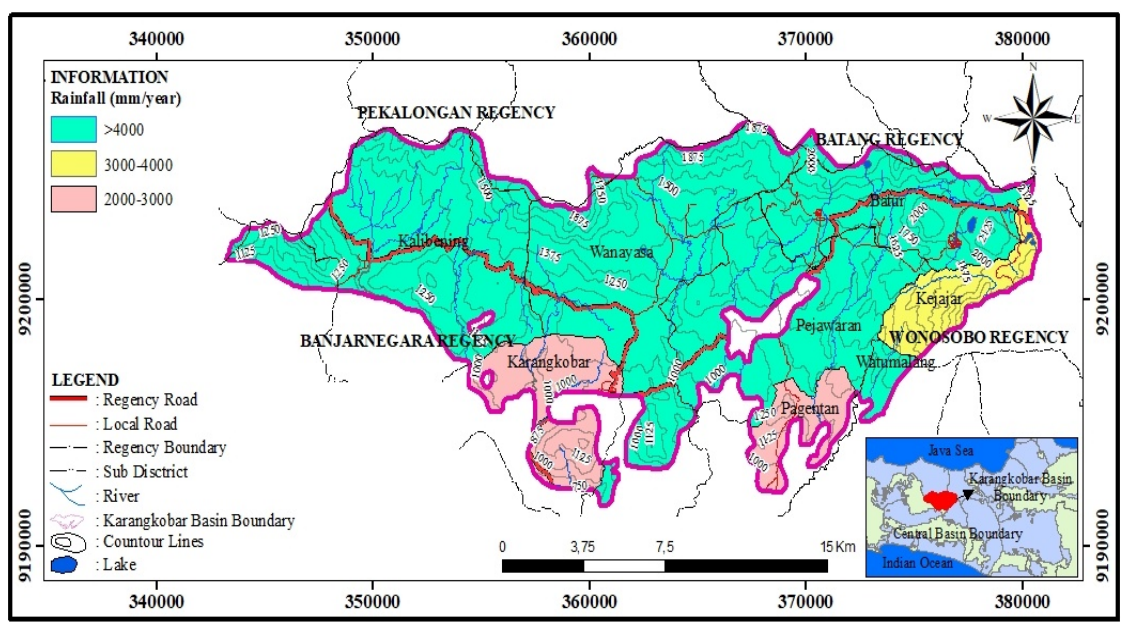

Gambar 4 Peta Parameter Curah Hujan (BPS Kabupaten Banjarnegara dan BPS Kabupaten Wonosobo, 2017)

Tabel 8 Perhitungan Skor Parameter Curah Hujan

\begin{tabular}{llll}
$\begin{array}{l}\text { Curah Hujan } \\
\text { (mm/tahun) }\end{array}$ & Nilai Peringkat & Nilai Bobot & Skor \\
\hline$>4.000$ & 5 & 4 & 20 \\
$3.000-4.000$ & 4 & 4 & 16 \\
$2.000-3.000$ & 3 & 4 & 12 \\
\hline
\end{tabular}

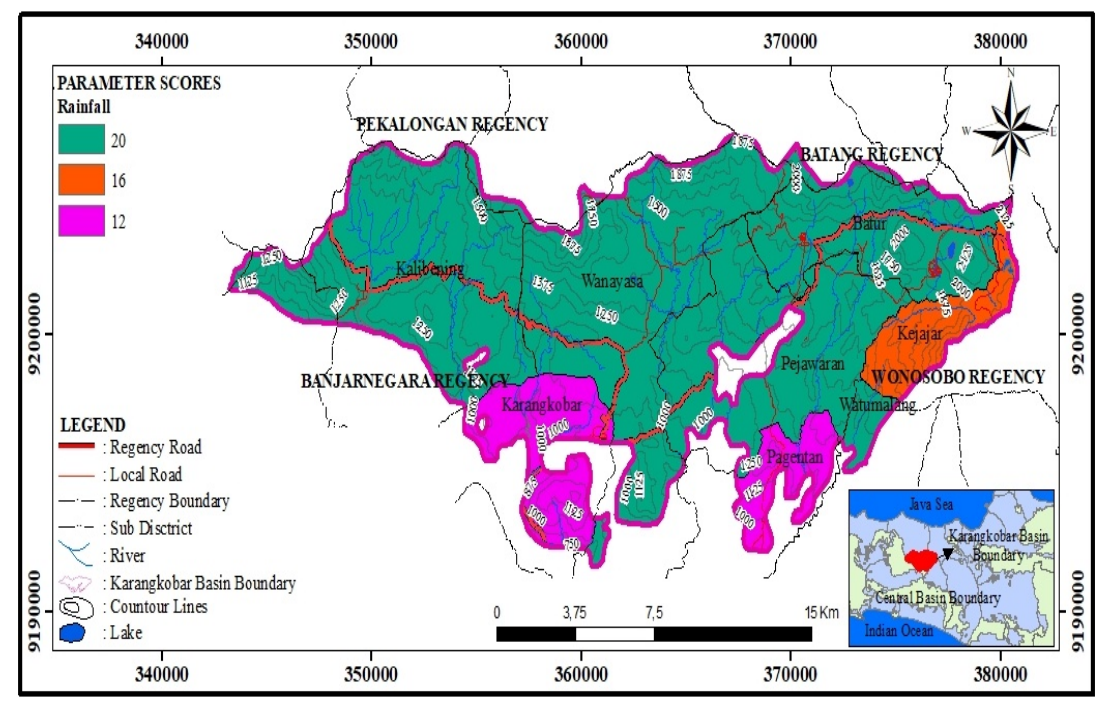

Gambar 5 Peta Skor Curah Hujan 
Daerah dengan curah hujan $>4.000 \mathrm{~mm} /$ tahun masuk kedalam peringkat 5 , sehingga nilai paringkat dikali dengan nilai bobot menghasilkan nilai skor 20 . Daerah dengan curah hujan 3.000-4.000 mm/tahun masuk kedalam peringkat 4 , sehingga nilai peringkat dikali dengan nilai bobot menghasilkan nilai skor 16 . Daerah dengan curah hujan 2.000-3.000 mm/tahun masuk kedalam peringkat 3 , sehingga nilai peringkat dikali dengan nilai bobot menghasilkan nilai skor 12 . Perhitungan ini dapat dilihat dalam Tabel 8 dan selanjutnya disajikan dalam pada peta skor curah hujan (Gambar 5)

\subsection{Parameter Jenis Tanah Penutup}

Parameter jenis tanah penutup memiliki nilai bobot 3 . Dari pengamatan lapangan dan juga data dari Bappeda Kabupaten Banjarnegara dan Kabupaten Wonosobo Tahun 2016, jenis tanah penutup yang ditemukan di lokasi penelitian sebagian besar ditutupi oleh kelompok tanah yang berasal dari lapukan batuan dari produk gunungapi, yaitu litosol, latosol, grumoso, organosol dan juga aluvial. Pembagian jenis tanah penutup dapat dibagi berdasarkan banyaknya jumlah lempung di dalam tanah. Sebaran jenis tanah penutup pada daerah penelitian dapat dikelompokkan sesuai dengan klasifikasi yang disiusun Danaryanto, (2007) dapat dilihat pada Tabel 9 dan persebarannya dalam Gambar 6 .

Tabel 9 Perhitungan Skor Parameter Jenis Tanah Penutup.

\begin{tabular}{lllll}
\hline $\begin{array}{l}\text { Jenis } \\
\text { Tanah }\end{array}$ & $\begin{array}{l}\text { Tanah } \\
\text { Penutup }\end{array}$ & $\begin{array}{l}\text { Nilai } \\
\text { Peringkat }\end{array}$ & $\begin{array}{l}\text { Nilai } \\
\text { Bobot }\end{array}$ & Skor \\
\hline $\begin{array}{l}\text { Litosol } \\
\text { Latosol } \\
\text { merah }\end{array}$ & Kerikilan & 5 & 3 & 15 \\
$\begin{array}{l}\text { Asosiasi } \\
\text { latosol, } \\
\text { pedzolik dan } \\
\text { organosol }\end{array}$ & Pasir kerikilan & 4 & 3 & 12 \\
$\begin{array}{l}\text { Lempung } \\
\text { pasiran }\end{array}$ & 3 & 3 & 9 \\
$\begin{array}{l}\text { Asosiasi } \\
\text { grumosol } \\
\text { dan aluvial }\end{array}$ & $\begin{array}{l}\text { Lanau } \\
\text { lempungan }\end{array}$ & 2 & & \\
\hline $\begin{array}{l}\text { Grumosol } \\
\text { Lempung }\end{array}$ & & & & \\
\hline
\end{tabular}

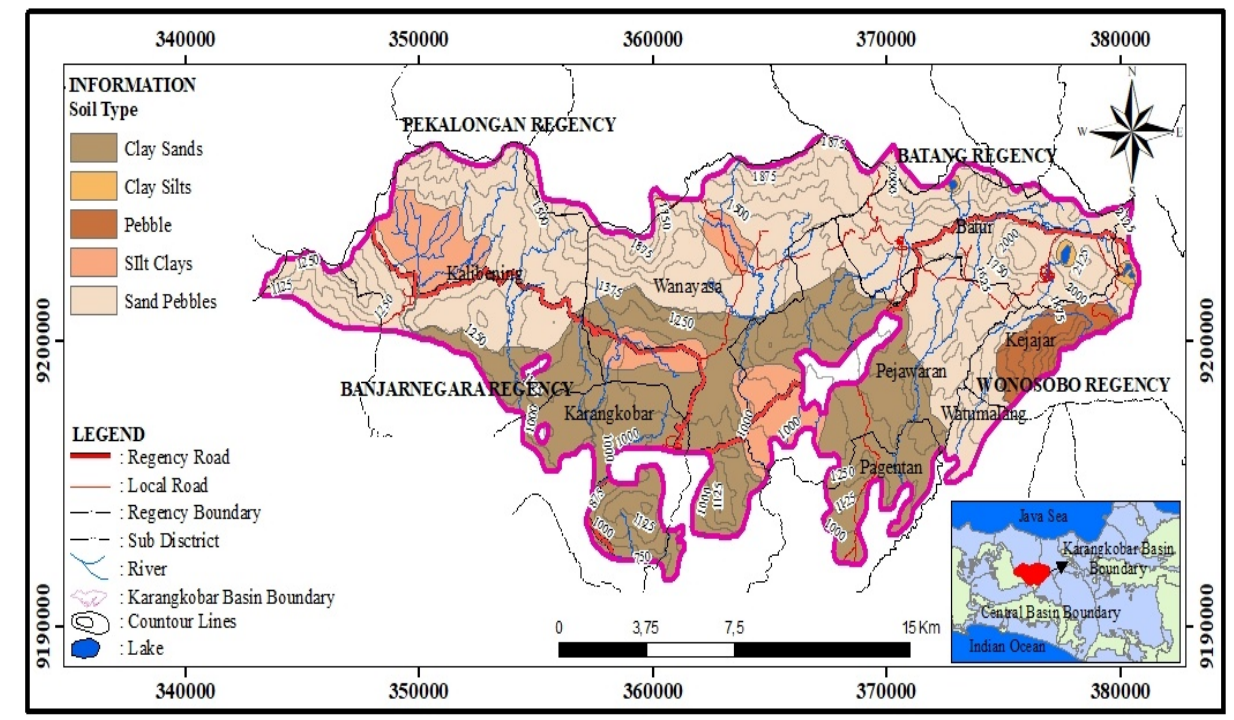

Gambar 6 Peta Jenis Tanah Penutup(Bappeda Kabupaten Banjarnegara dan Kabupaten Wonosobo 2016)

Dari jenis tanah tersebut, daerah penelitian dapat digolongkan menjadi 5 jenis tanah, yaitu jenis tanah kerikilan, lempung pasiran, lanau lempungan dan lempung lanauan. Tanah litosol dan masuk 
kedalam tanah jenis kerikilan, hal ini karena tanah litosol banyak mengandung kerikil dan pasir serta jumlah lempung yang sedikit sehingga mampu merasapkan air dengan baik. Jenis tanah ini memiliki peringkat 5, sehingga nilai peringkat dikalikan dengan nilai bobot memiliki nilai skor 15 .

Tanah latosol masuk kedalam jenis tanah pasir kerikilan sehinggga memiliki nilai peringkat 4. Nilai peringkat dikalikan dengan nilai bobotnya menghasilkan nilai 12. Tanah asosiasi latosol, pedzolik dan organosol merupakan tanah yang memiliki sifat yang plastis dan liat namun memiliki kandungan pasir sehingga dikategorikan menjadi jenis tanah lempung pasiran. Jenis tanah ini memiliki nilai peringkat 3, dengan demikian nilai skornya adalah 9. Tanah asosiasi grumosol dan aluvial merupakan jenis tanah yang liat, plastis dan kondisinya basah, jenis tanah ini masuk kedalam jenis tanah lanau lempungan dengan nilai bobot 2 , sehingga nilai bobot dikalikan dengan nilai peringkat menghasilkan skor sebesar 6. Tanah grumosol merupakan jenis tanah yang memiliki porositas dan kebundaran yang sangat baik dan tidak dapat meloloskan air, jenis tana ini masuk kedalam jenis tanah lempung lanauan dan memiliki nilai bobot 1 , sehingga nilai bobot dan nilai parameter dikalikan menghasilkan nilai skor sebesar 3. Perhitungan skor jenis tanah penutup disajikan dalam Tabel 3. Peta skor tanah penutup disajikan dalam Gambar 7

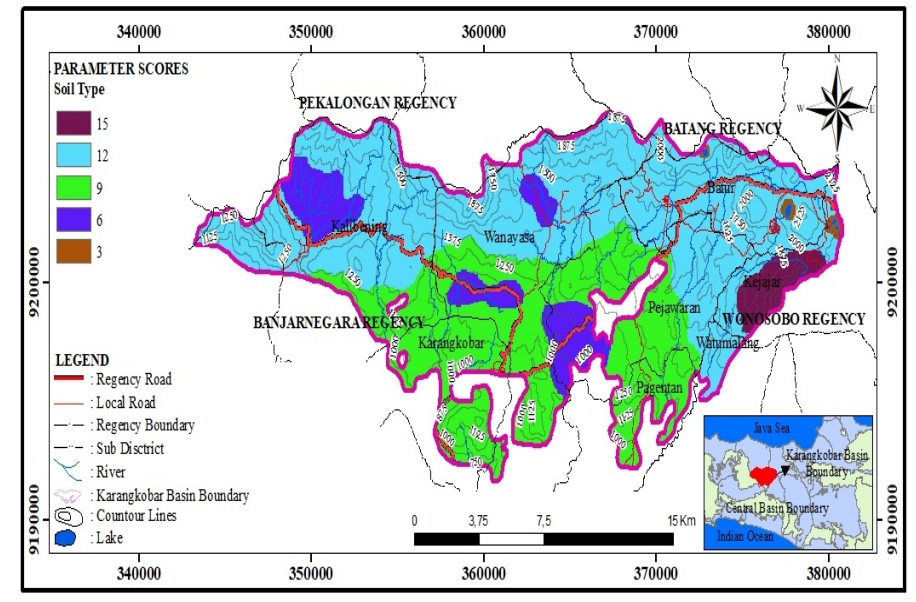

Gambar 7 Peta Skor Tanah Penutup

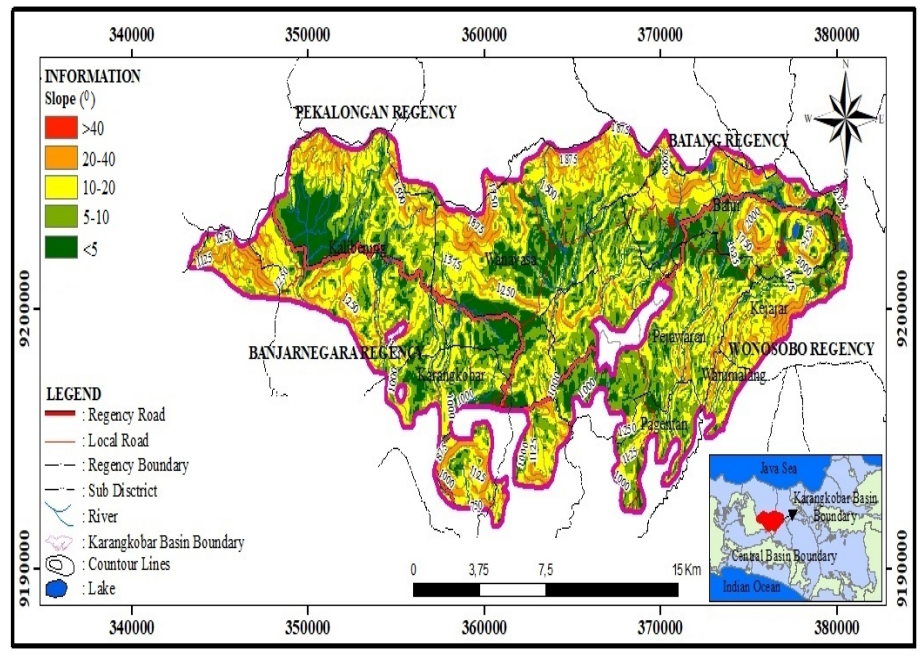

Gambar 8 Peta Kemiringan Lereng

\subsection{Parameter Kemiringan Lereng}

Parameter kemiringan lereng memiliki nilai bobot 2 . Kemiringan lereng pada suatu daerah akan sangat mempengaruhi proses peresapan air. Semakin besar nilai derajat kemiringan maka akan semakin mudah jumlah air yang meresap ke dalam tanah. Kemiringan lereng ini juga dipengaruhi oleh faktor infiltrasi untuk beberapa jenis kemiringan. Daerah penelitian ini memiliki nilai kemiringan yang bervariasi seperti yang dapat dilihat pada Gambar 8 .

Daerah penelitian memiliki kelerengan yang berkisar dari $0-60^{\circ}$. Variasi derajat kemiringan lereng pada daerah penelitian ini dapat diklasifikasikan menjadi 5 daerah. Daerah dengan kemiringan lereng sebesar $>40^{\circ}$ daerah ini memiliki peringkat 5, sehingga nilai bobotnya adalah 10 . Daerah dengan kemiringan lereng sebesar $20^{\circ}-40^{\circ}$ daerah ini 
memiliki peringkat 4 , sehingga nilai bobotnya adalah 8. Daerah dengan kemiringan lereng sebesar $10^{\circ}-20^{\circ}$ masuk dalam peringkat 3 , sehingga nilai peringkat dikalikan dengan nilai bobot adalah 6 . Daerah dengan kemiringan lereng $5^{\circ}-10^{\circ}$, masuk kedalam perigkat 2 , sehingga nilai peringkat dikalikan dengan nilai bobot menghasilkan nilai skor 4. Daerah dengan kimiringan lereng $<5^{\circ}$, masuk ke dalam peringkat 1 , sehingga nilai peringkat dikalikan nilai bobot memiliki nilai skor 2.

Perhitungan skor nilai kemiringan lereng dapat dilihat dalam Tabel 10. Peta skor kemiringan lereng disajikan dalam Gambar 9.

Tabel 10 Perhitungan Skor Parameter Kemiringan Lereng.

\begin{tabular}{llll}
\hline Kemiringan Lereng & $\begin{array}{l}\text { Nilai } \\
\text { Peringkat }\end{array}$ & $\begin{array}{l}\text { Nilai } \\
\text { Bobot }\end{array}$ & Skor \\
\hline$>40^{\circ}$ & 5 & 2 & 10 \\
$20-40^{\circ}$ & 4 & 2 & 8 \\
$10-20^{\circ}$ & 3 & 2 & 6 \\
$5-10^{\circ}$ & 2 & 2 & 4 \\
$<5^{\circ}$ & 1 & 2 & 2 \\
\hline
\end{tabular}

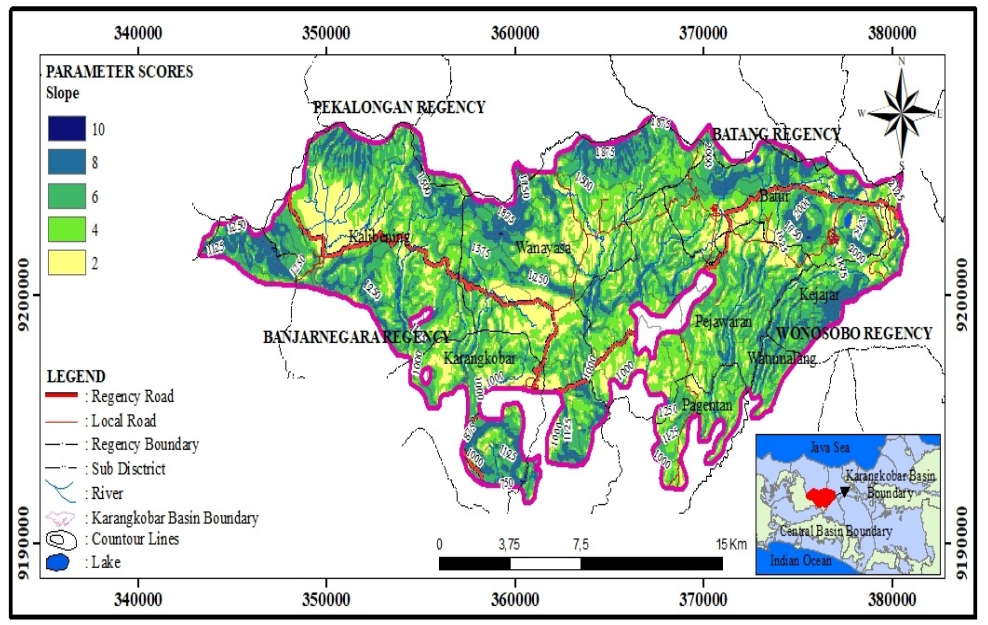

Gambar 9 Peta Skor Kemiringan Lereng

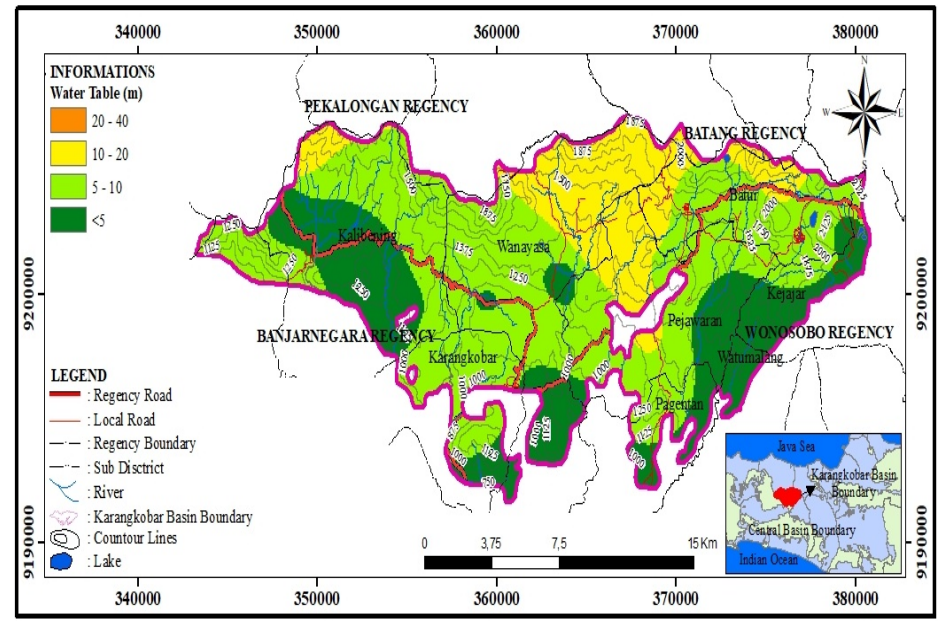

Gambar 10 Peta Skor Kemiringan Lereng

\subsection{Parameter Kedalaman Muka Air Tanah Tidak Tertekan}

Kedalaman muka air tanah merupakan parameter yang kelima dengan nilai bobot 1 . Nilai satu ini menunjukkan bahwa parameter ini adalah parameter yang paling kurang berpengaruh dalam penelitian ini dan juga menunjukkan bahwa parameter ini adalah parameter yang paling kurang spesifik dalam menunjukkan daerah imbuhan air tanah. Kedalaman muka air tanah adalah jarak minimun muka tanah terhadap permukaan air tanah. Semakin dalam muka air tanah maka air akanlebih mudah lolos atau bermigrasi ke dalam tanah secara 
vertikal. Semakin dangkal muka air tanah akan semakin menunjukkan ciri-ciri daerah imbuhan air tanah.

Kedalaman muka air tanah dangkal pada daerah penelitian diperoleh dari elevasi muka air tanah dangkal. Dari pengukuran muka air tanah terdapat data kedalaman muka air tanah yang berkisar antara 1,3-12,5 m (Tabel 11).

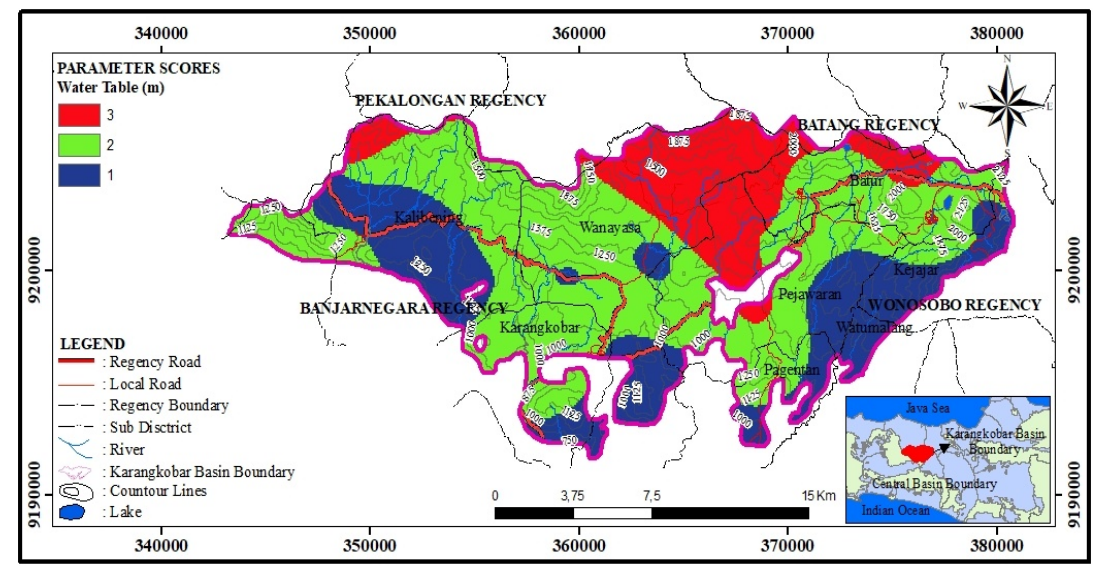

Gambar 11 Peta Skor Kedalaman Muka Air tanah Tidak Tertekan

Tabel 11 Nilai Kedalaman Muka Air tanah Tidak Tertekan

\begin{tabular}{|c|c|c|c|c|c|}
\hline No & \multicolumn{2}{|c|}{ Koordinat } & $\begin{array}{c}\text { Elevasi } \\
\text { (mdpl) }\end{array}$ & $\begin{array}{c}\text { MAT } \\
\text { (mdpl) }\end{array}$ & $\begin{array}{c}\text { Kedalam } \\
\text { an (m) }\end{array}$ \\
\cline { 2 - 3 } & $\mathbf{x}$ & $\mathbf{y}$ & 1407 & 1404 & 3 \\
\hline 1 & 371553 & 9198642 & 1407 & 6 \\
\hline 2 & 373423 & 9202075 & 1628 & 1622 & 8 \\
\hline 3 & 360534 & 9196333 & 1015 & 1007 & 6 \\
\hline 4 & 364403 & 9197334 & 1039 & 1033 & 6 \\
\hline 5 & 365272 & 9197658 & 1058 & 1053 & 5 \\
\hline 6 & 362017 & 9196213 & 1055 & 1053,5 & 1,5 \\
\hline 7 & 362237 & 9198507 & 1280 & 1270 & 10 \\
\hline 8 & 369105 & 9196649 & 1217 & 1209 & 8 \\
\hline 9 & 368601 & 9198453 & 1290 & 1278 & 12 \\
\hline 10 & 370495 & 9202821 & 1643 & 1634 & 9 \\
\hline 11 & 370707 & 9203328 & 1628 & 1621 & 7 \\
\hline 12 & 351191 & 9202026 & 1063 & 1061,4 & 1,6 \\
\hline 13 & 349931 & 9201415 & 1052 & 1050,5 & 1,5 \\
\hline 14 & 355195 & 9200947 & 1343 & 1338 & 5 \\
\hline 15 & 366491 & 9202818 & 1441 & 1423 & 18 \\
\hline 16 & 364901 & 9201818 & 1340 & 1327,5 & 12,5 \\
\hline 17 & 368819 & 9201417 & 1530 & 1520,4 & 9,6 \\
\hline 18 & 377424 & 9203876 & 2008 & 1999 & 9 \\
\hline 19 & 379516 & 9203673 & 2102 & 2094 & 8 \\
\hline 20 & 379466 & 9202756 & 2035 & 2031,6 & 3,4 \\
\hline 21 & 379388 & 9201552 & 2036 & 2031 & 5 \\
\hline 22 & 377105 & 9202098 & 1970 & 1963 & 7 \\
\hline 23 & 375891 & 9204106 & 1917 & 1906 & 11 \\
\hline 24 & 349663 & 9201177 & 1070 & 1062 & 8 \\
\hline 25 & 349349 & 9201913 & 1150 & 1146 & 4 \\
\hline 26 & 348584 & 9203873 & 1070 & 1068 & 2 \\
\hline 27 & 348982 & 9205072 & 1063 & 1050 & 13 \\
\hline 28 & 350426 & 9202326 & 1048 & 1046,7 & 1,3 \\
\hline 29 & 361077 & 9199790 & 1170 & 1164,2 & 5,8 \\
\hline 30 & 360867 & 9200666 & 1160 & 1153,5 & 6,5 \\
\hline 31 & 359694 & 9199687 & 1140 & 1135,4 & 4,6 \\
\hline 32 & 363777 & 9200729 & 1380 & 1378 & 2 \\
\hline 33 & 363581 & 9202661 & 1423 & 1412 & 11 \\
\hline 170 & & & & & \\
\hline
\end{tabular}

Berdasarkan klasifikasi Danaryanto dkk. (2007), daerah penelitian dapat dibagi menjadi 3 kelas (Gambar 10).

Daerah dengan kedalam 10-20 m masuk kedalam peringkat 3 , sehingga nilai peringkat dikali nilai bobotnya adalah 3. Daerah dengan kedalaman muka air tanah 5-10 m masuk kedalam peringkat 2, sehingga nilai peringkat dikalikan dengan nilai bobotnya adalah 2. Daerah paling rendah adalah daerah dengan kedalaman muka air tanah $<5 \mathrm{~m}$, daerah ini masuk kedalam peringkat 1 , sehingga nilai peringkat dikalikan dengan nilai bobot nilainya adalah 1.

Hasil perhitungan dapat dilihat pada Tabel 12 dan disajikan dalam bentuk peta skorkedalaman muka air tanah tidak tertekan pada Gambar 11.

Tabel 12 Perhitungan Skor Parameter Kedalaman Muka Air tanah Tidak Tertekan.

\begin{tabular}{llll}
\hline $\begin{array}{l}\text { Kedalaman Muka Air tanah } \\
\text { Tidak Tertekan } \\
(\mathrm{m})\end{array}$ & $\begin{array}{l}\text { Nilai } \\
\text { Peringkat }\end{array}$ & $\begin{array}{l}\text { Nilai } \\
\text { Bobot }\end{array}$ & Skor \\
\hline $10-20 \mathrm{~m}$ & 3 & 1 & 3 \\
$5-10 \mathrm{~m}$ & 2 & 1 & 2 \\
$<5 \mathrm{~m}$ & 1 & 1 & 1 \\
\hline
\end{tabular}

\subsection{Hasil Pembobotan}

Hasil pembobotan merupakan jumlah setiap nilai parameter setelah peringkat dikalikan dengan nilai bobotnya (Persamaan 2.1). Daerah dengan nilai tertinggi merupakan daerah yang berpotensi untuk menjadi daerah imbuhan, sedangkan daerah dengan nilai terendah merupakan daerah lepasan (Danaryanto dkk. 2007). 
Dari hasil pembobotan nilai maksimum yang didapat adalah 65 , sedangkan nilai minimum adalah 39 (Gambar12).

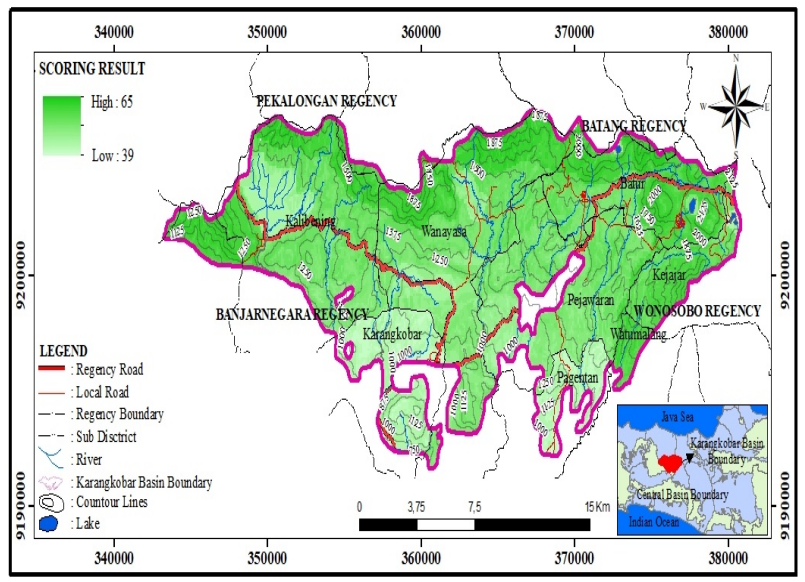

Gambar 12 Peta Hasil Pembobotan

Berdasarkan klasifikasi Danaryanto dkk. (2007) daerah tersebut seluruhnya adalah daerah imbuhan karena nilainya berada diatas 33, sehingga perlu dilakukan modifikasi dengan menaikkan nilai batas antara zona imbuhan dan zona lepasan yaitu dengan nilai batas 52 . Nilai 52 didapat dari nilai tengah antara batas nilai maksimum dikurangi dengan nilai minimumnya, lalu nilai tengah tersebut dijumlahkan dengan nilai minimumnya, didapatkan nilainya adalah 52. Daerah dengan nilai $>52$ merupakan daerah yang berpotensi menjadi daerah imbuhan utama, sedangkan daerah dibawah $\leq 52$ merupakan daerah imbuhan tidak berarti dengan kata lain adalah daerah lepasan air tanah. Secara umum daerah imbuhan air tanah berada di bagian utara sedangkan daerah lepasan berada di bagian selatan CAT Karangkobar (Gambar 13). Pembagian daerah imbuhan dan daerah lepasan disajikan dalam Tabel 13.

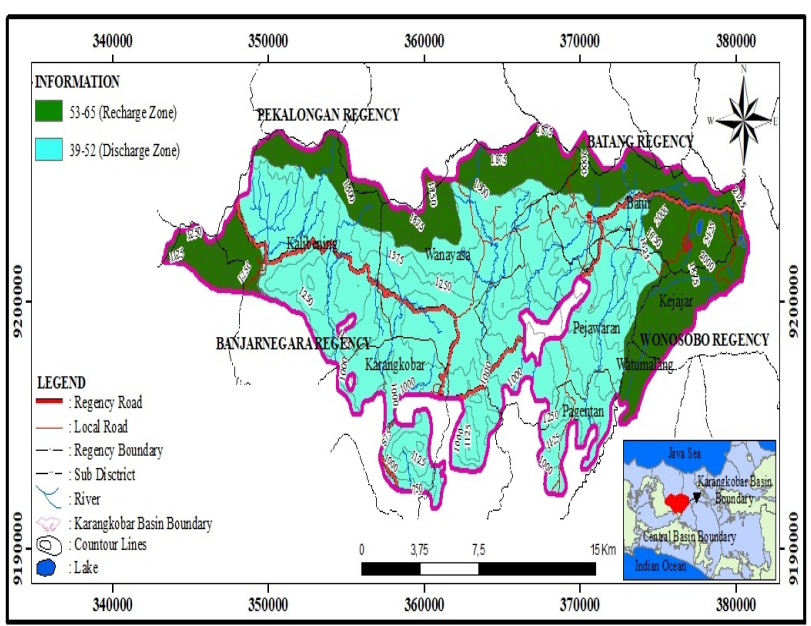

Gambar 13 Peta Daerah Imbuhan dan Daerah Lepasan CAT

$$
\text { Karangkobar }
$$

\section{Kesimpulan}

Terdapat lima parameter dalam penentuan daerah imbuhan dan lepasan pada CAT Karangkobar, yaitu kelulusan batuan terdiri dari 2 kelas $\left(10^{1}-10^{3}\right.$ dan $\left.10^{-2}-10^{1}\right)$; curah hujan terdiri dari 3 kelas $(>4000$, 3.000-4.000, 2.000-3.000); jenis tanah penutup terdiri dari 5 kelas (kerikilan, pasir kerikilan, lempung pasiran, lanau lempungan, lempung lanauan); kemiringan lereng $\left(>40^{\circ}, 20-40^{\circ}, 10-20^{\circ}, 5-10^{\circ},<5^{\circ}\right)$; dan kedalaman muka air tanah terdiri dari 3 kelas (10-20 m, 5-10 m, <5 m).

Tabel 13 Zonasi Daerah Imbuhan dan Lepasan Air tanah.

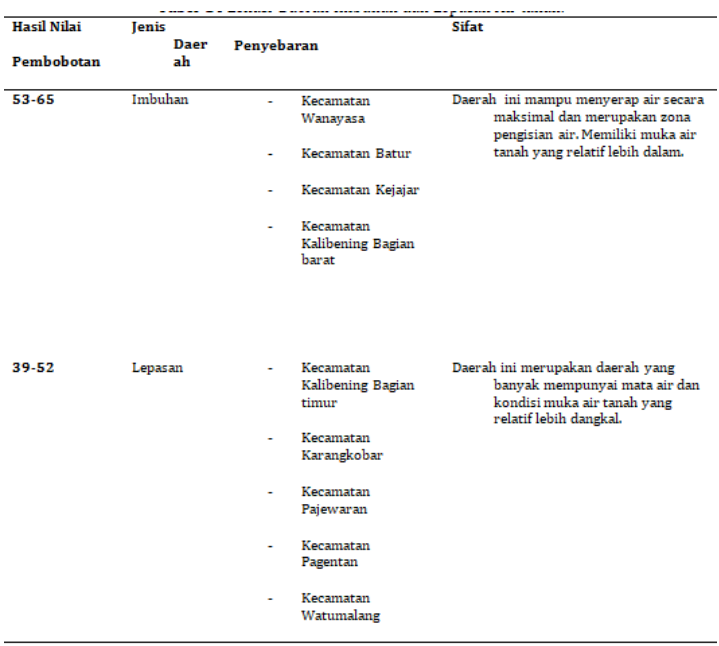

Dari hasil pembobotan nilai setiap parameter, nilai yang didapat berkisar antara 39-65. Nilai batas yang digunakan untuk memisahkan daerah imbuhan dan daerah lepasan adalah 53. Berdasarkan modifikasi klasifikasi Danaryanto, dkk. (2007), daerah imbuhan air tanah berada pada nilai 53-65 yang berada di bagian utara dari daerah penelitian, tepatnya berada di Kabupaten Banjarnegara pada Kecamatan Kalibening bagian utara, Kecamatan Wanayasa di bagian utara, dan Kecamatan Batur bagian utara dan timur laut serta Kabupaten Wonosobo tepatnya di Kecamatan Kejajar bagian Utara. Sedangkan untuk zona lepasan air tanah berada pada nilai 39-52 yang terletak di bagian selatan dan tengah daerah penelitian yaitu di Kabupaten Banjarnegara tepatnya di Kecamatan Karangkobar, Kecamatan Wanayasa, Kecamatan Pejawaran dan Kecamatan Kejajar bagian selatan.

\section{DAFTAR PUSTAKA}

Assatse, W,T., Noucka, P,N., Tabod, C,T., Akamed, J,M., Biringanineab, G,N. 2016. Hydrogeological activity of lineaments in Yaoundé Cameroon region using remote sensing and gis techniques. The Egyptian Journal of Remote Sensing and Space Sciences.19: 49-60. Cameroon.

https://www.sciencedirect.com/science/article/pii/ S1110982315000769

Badan Pusat Statistik Kabupaten Banjarnegara. 2016. Kabupaten Banjarnegara Dalam Angka 2016. Banjarnegara.

Badan Pusat Statistik Kabupaten Wonosobo. 2016. Kabupaten Wonosobo Dalam Angka 2016. Wonosobo.

Bakosurtanal. 2009. Peta Rupa Bumi Indonesia. Provinsi Jawa Tengah dan Daerah Istimewa Yogyakarta. 
Bappeda Kabupaten Banjarnegara. 2011. Peta Jenis Tanah Kabupaten Banjarnegara. Banjarnegara.

Bappeda Kabupaten Wonosobo. 2011. Peta Jenis Tanah Kabupaten Wonosobo. Wonosobo

Condon, W.H., Pardyantom, L., Ketner K.B., Amin T.C., Gafoer S., dan Samodra H., 1996. Peta Geologi skala 1:175.000.Lembar Banjarnegara dan Pekalongan. Edisi Kedua. Pusat Penelitian dan Pengembangan (PUSLITBANG) Geologi. Bandung.

Danaryanto, T. H., Setiadi H., dan Siagian Y. 2007. Kumpulan Pedoman Teknis Pengelolaan Air tanah. Badan Geologi: Bandung.

Dinas Energi Sumber Daya Mineral (ESDM). 2009. Potensi Cekungan Air tanah (CAT) Karangkobar. ESDM. Semarang.

Dinas Energi Sumber Daya Mineral (ESDM). 2017. Penyusunan Zona Pemanfaatan dan Konservasi Air tanah Pada Cekungan Air tanah (CAT) Karangkobar. ESDM. Semarang.

Elbeih, S, F. 2015. An overview of integrated remote sensing and gis for groundwater mapping in egypt. Ain Shams Engineering Journal. 6: 1-15. Cairo.

https://www.sciencedirect.com/science/article/pii/ S2090447914001129

Lewis, D, B. 2016. Response of wetland soil carbon to groundwater conservation: Probabilistic outcomes from error propagation. Ecological Indicators, Volume 60: 538-547.

https://www.sciencedirect.com/science/article/pii/S1470 $160 \times 15003611$

Magesh, N.S., Chandrasekar, N., and Soundranayagam, J.P. 2012. Delineation of Groundwater Potential Zones in Theni District, Tamil Nadu, using remote sensing, GIS and MIF Techniques. Geosciences Frontiers 3 (2) (2012) 189-196.

https://www.sciencedirect.com/science/article/pii/S1674 987111001137?via\%3Dihub

Mahavidanage, M.D.S.R.A. 2011. Geospatial analysis concepts with gis and remote sensing technology for ornithology. $20^{\text {th }} \quad$ Bird Watchers Conference.University of Colombo School of Computing (UCSC):Srilanka. https://www.researchgate.net/publication/2359201 67.

Peraturan Menteri ESDM Nomor 13 Tahun 2009. Tentang Pedoman Penyusunan Rancangan Penentapan Cekungan Air tanah.

Peraturan Menteri ESDM Nomor 2 Tahun 2017. Tentang Cekungan Air tanah Indonesia.

Riastika, M. 2011. Pengelolaan air tanah berbasis konservasi di recharge area Boyolali (Studi kasus recharge Area Cepogo, Boyolali, Jawa Tengah). Jurnal Ilmu Lingkungan. Universitas Diponegoro. 2: 86-97. Semarang.

https://ejournal.undip.ac.id/index.php/ilmulingkungan/ar ticle/view/4073

Rose, S. 2009. Groundwater recharge and discharge. Groundwater.Georgia State University. 3: 65-75. Atlanta.https://www.eolss.net/SampleChapters/C07/E2-09-06-07.pdf

Said, H.D., dan Sukrisno. 1988. Peta Hidrogeologi Regional Skala 1:175.000 Lembar Pekalongan. Pusat penelitian dan Pengembangan (PUSLITBANG) Geologi:Bandung.

Senayake, I.P, Dissanayake, D.M.D.O.K., Mayadunna, B.B., and Weerasekera, W.I. 2016. An approach to delineate groundwater recharge potential sites in Ambalantota,
Sri Lanka using GIS techniques.Geosciences Frontiers 7: 115-124. Beijing.

https://www.sciencedirect.com/science/article/pii/S1674 987115000390

Todd, D. K dan Mays, L. W. 2005. Groundwater Hydrology, 3rd Edition. John Wiley \& Sons, New York.

Unwin, J. 1996. Gis, Spatial analysis and spatial statistics. University of London.540-551.London. http://journals.sagepub.com/doi/pdf/10.1177/0309 13259602000408

Yeh, H.F., Cheng, Y.S., Lin, H.I, and Lee, C.H. 2016. Mapping groundwater recharge potential zone using a GISApproach in Hualian River, Taiwan. Sustainable Environment Research 26: 33-43. Taiwan 